Book Review

\title{
Business and Accounting Ethics in Islam
}

\section{By Trevor Gambling and Rifaat Ahmed Abdel Karim. London: Mansell, 1991, 152 pp.}

The present book represents the first serious attempt to explore Islamic business and accounting ethics. After placing their subject in a broad Islamic framework, which they have documented quite ably, they then compare the distinctive features of Islamic business and accounting principles with Western theory and practice. While the book has several strong points and breaks new ground in a number of areas, it also lacks clarity and specific authority from Islamic sources on quite a few points.

To begin with, the authors argue quite convincingly that the logical corollary of prohibiting rib $\bar{a}$ (interest) is the negation of any time value for money. Thus the theory and practice of capital budgeting, which feature in the use discounted cash flow techniques in the West, become redundant. This point, seemingly so obvious to economists, has not found favor with the economic thinking of the Islamic establishment. Rather, many Muslim economists and accountants have been busy justifying it on one pretext or another. This is the first time that somebody has come out with a compelling discussion of this question.

The authors have also argued that Islam absolutely forbids the nonrepayment of a debt. Thus the concept of limited liability, one of mainsprings of economic power in a capitalist society, is not recognized by Islam. However, the related theory of incorporation, the legal mechanism for justifying limited liability, is found in Islamic societies. Again, such an obvious and sensible point remains unacceptable to Muslim economists. They continue looking for excuses to accept these ideas, thereby betraying their intellectual poverty.

Although the authors do not devote a single chapter to the state's economic role in Islam, they discuss this question throughout the book. They argue for a strong regulatory and framework role for the Islamic state.

Gambling and Abdel Karim deal with several other important issues. For instance, they argue that the Islamic concept of economic development revolves around the development of human resources rather than capital formation, as is the main focus of the popular theory of development in the West. In their discussion of the Islamic concept of shürä (consultation) and khiläfah (vice-gerency), they also break new ground. They opine that these concepts 
suggest that a business manager and a business owner consult his/her partners, employees, customers, and creditors on a wide variety of matters. In this way, a partner will be unable to withdraw his/her investment share without first consulting the other partners. Similarly, the purchase of an existing business by an anonymous person will be made impossible. This mechanism does away with a number of modern evils: mergers, takeovers, speculation, insider trading, and playing with others' funds to reap unearned incomes, to name just a few. One unique contribution of the authors is their argument that an "absentee investor" is as unacceptable to Islam as is an "absentee landlord." No one has drawn this conclusion earlier, and it contains a lot of food for thought.

Finally, Gambling and Abdel Karim state that Islam views accounting solely as a tool to determine how much of one's wealth is subject to zakah. While this idea needs some reconsideration, as there is nothing in Islam which restricts accounting to this sole function, they do draw several interestinq conclusions. For example, since determining the amount of zakah has to be done on the basis of net realizable wealth, an Islamic framework cannot accept Western accounting concepts like conservatism, going concern, periodicity, and others. Similarly, the Islamic concept takes care of inflation, thereby voiding the need for a separate accounting to deal with it. These are exciting new ideas, and Muslim thinkers should pay attention to them.

However, there are certain ideas which need clarification. Among them are: the discussion of commercial leasing in Islam (p. 38); the idea that the lower marginal utility of wealth for the rich leads to hoarding (p. 54); the Islamic position on tariffs (p. 57); government bonds (p. 59); the ummah's right to know what is going on in business (p. 60); and the concepts of just wages, just prices, and just rewards (p. 120).

There are some points on which it seems difficult to agree with the authors. For example, they support licensing by the government (p. 57), although the implications of this practice for the distribution of income have been widely discussed in the literature. Similarly, they argue that auditors in an Islamic state do not need to look for compliance with the Shari'ah. This is an unnecessary restriction. In fact, all auditors should report on this aspect if we want Islamic institutions to survive the onslaught of human machinations.

Lastly, the authors have not been careful in transliterating Islamic terms. For example, the terms qard hasan, rikäz, and 'ushr have been spelled incorrectly. It is my opinion that a glossary of terms at the end of the book would have increased its value for non-Muslim readers.

Muhammad Akram Khan

Pakistan Auditing and Accounting Services

Lahore, Pakistan 